University of Nebraska - Lincoln

DigitalCommons@University of Nebraska - Lincoln

Faculty Publications from the Harold W. Manter Laboratory of Parasitology

2012

\title{
Four Events of Host Switching in Aspidoderidae (Nematoda) Involve Convergent Lineages of Mammals
}

\author{
F. Agustín Jiménez-Ruiz \\ Southern Illinois University Carbondale, agustinjz@zoology.siu.edu \\ Scott Lyell Gardner \\ University of Nebraska - Lincoln, slg@unl.edu \\ Graciela Navone \\ Southern Illinois University Carbondale \\ Guillermo Ortí \\ George Washington University
}

Follow this and additional works at: https://digitalcommons.unl.edu/parasitologyfacpubs

Part of the Behavior and Ethology Commons, Biodiversity Commons, Parasitology Commons, Terrestrial and Aquatic Ecology Commons, and the Zoology Commons

Jiménez-Ruiz, F. Agustín; Gardner, Scott Lyell; Navone, Graciela; and Ortí, Guillermo, "Four Events of Host Switching in Aspidoderidae (Nematoda) Involve Convergent Lineages of Mammals" (2012). Faculty Publications from the Harold W. Manter Laboratory of Parasitology. 766.

https://digitalcommons.unl.edu/parasitologyfacpubs/766

This Article is brought to you for free and open access by the Parasitology, Harold W. Manter Laboratory of at DigitalCommons@University of Nebraska - Lincoln. It has been accepted for inclusion in Faculty Publications from the Harold W. Manter Laboratory of Parasitology by an authorized administrator of DigitalCommons@University of Nebraska - Lincoln. 


\title{
FOUR EVENTS OF HOST SWITCHING IN ASPIDODERIDAE (NEMATODA) INVOLVE CONVERGENT LINEAGES OF MAMMALS
}

\author{
F. Agustín Jiménez, Scott L. Gardner*, Graciela Navone, and Guillermo Ortí \\ Department of Zoology, Southern Illinois University, Carbondale, Illinois 62901-6501.e-mail: agustinjz@zoology.siu.edu
}

\begin{abstract}
The Great American Interchange resulted in the mixing of faunistic groups with different origins and evolutionary trajectories that underwent rapid diversification in North and South America. As a result, groups of animals of recent arrival converged into similar habits and formed ecological guilds with some of the endemics. We present a reconstruction of the evolutionary events in Aspidoderidae, a family of nematodes that infect mammals that are part of this interchange, i.e., dasypodids, opossums, and sigmodontine, geomyid, and hystricognath rodents. By treating hosts as discrete states of character and using parsimony and Bayesian inferences to optimize these traits into the phylogeny of Aspidoderidae, we reconstructed Dasypodidae (armadillos) as the synapomorphic host for the family. In addition, 4 events of host switching were detected. One consisted of the switch from dasypodids to hystricognath rodents, and subsequently to geomyid rodents. The remaining set of events consisted of a switch from dasypodids to didelphid marsupials and then to sigmodontine rodents. The reconstruction of the ancestral distribution suggests 3 events of dispersal into the Nearctic. Two of these invasions would suggest that 2 different lineages of dasypodid parasites entered the Northern Hemisphere at different times, which is consistent with the presence of 2 lineages of armadillos in Mexico.
\end{abstract}

Parasites establish themselves in individuals that offer the resources necessary for their survival, growth, and reproduction (Smyth, 1962). This establishment also depends on the chance of parasites and host to encounter each other and on their compatibility (Combes, 1991). The resources a parasite depends on may be available in individuals from an ecological guild or be unique to a group sharing a common ancestor (Choudhury and Dick, 2001). In the latter case, specificity of the parasites toward their hosts would be reflected in taxonomic concordance among the associates (Choudhury and Dick, 2001). Vicariant speciation in organisms serving as hosts may result in the isolation and subsequent speciation of their parasites (Light and Hafner, 2008). However, potential hosts may belong to different taxonomic groups occurring in sympatry, forming an ecological guild. In this case, the physical proximity of potential hosts may have an effect on the distribution of parasites in their hosts and result in ecological or evolutionary patterns different from cospeciation (Janzen, 1980; Choudhury and Dick, 2001; Weckstein, 2004; Huyse and Volckaert, 2005; Bueter et al., 2009). Discerning evolutionary patterns from ecological associations may be difficult because the distribution of parasites in a diverse array of hosts may follow temporary changes in the distribution and availability of the hosts, as well as changes in traits present in both parasites and hosts (Janzen, 1980; Kelly et al., 2009; Agosta et al., 2010).

The extant distribution of parasites in their hosts is used as the foundation for the reconstruction of historical associations. In the case of cophylogenetic studies, the associations should be studied using different methods so patterns of cophylogeny can be contrasted with stochasticity (Light and Hafner, 2008). These methods can be grouped as either data-based (Kishino and Hasegawa, 1989; Huelsenbeck and Rannala, 1997) or topologybased (Charleston, 1998; Ronquist, 2001). The premise of these methods is the optimization of reciprocally congruent trees known without error. As a consequence, these methods may not

Received 23 November 2011; revised 7 May 2012; accepted 4 June 2012. * Department of Biological Sciences, The George Washington University, 2023 G St. NW, Washington, D.C. 20052.

$\uparrow$ The Harold W. Manter Laboratory of Parasitology, University of Nebraska-Lincoln, Lincoln, Nebraska 68588-0547, and Centro de Estudios Parasitológicos y de Vectores- CEPAVE- CONICET-UNLP Calle 2 Número 584 (1900) La Plata, Argentina.

DOI: 10.1645/GE-3045.1 perform optimally in reconstructing historical associations between parasites occurring in distantly related hosts (not sharing an immediate common ancestor). In these cases, reconstruction of historical associations can be achieved by treating hosts as traits to be optimized in the parasite phylogeny. Diverse methods facilitate the reconstruction of ancestral states, including hosts, by framing the distribution of the traits into the phylogeny of a group of organisms. These include optimization using parsimony (Brooks, 1985; Ronquist, 2003), maximum likelihood (Huelsenbeck and Rannala, 1997), and Bayesian approaches (Huelsenbeck et al., 2000; Pagel et al., 2004).

The New World experienced rapid faunistic changes as the result of dispersal of organisms from South to North America and vice versa due to geological and biotic factors (Simpson, 1980). This phenomenon, known as the Great American Interchange, resulted in the evolutionary diversification of several groups with different origins and evolutionary trajectories (D'Elía, 2003; Opazo, 2005; Poux et al., 2006; Weksler, 2006; Dunnum and Salazar-Bravo, 2010). As a result of this diversification, some of these groups converged to exhibit similar habits, as well as morphological and even physiological features. This includes semifossorial habits and similar metabolic rates observed in insectivorous and semi-insectivorous mammals like armadillos, opossums, and sigmodontine rodents (McNab, 1984). This faunal diversification and subsequent convergence may increase the spectrum of host species that may offer compatibility with the parasites already established in a single area.

The Aspidoderidae Skrjabin and Schikhobalova, 1947 (Ascaridida: Heterakoidea) currently includes 17 species divided among 4 genera. These nematodes occur in the cecum and large intestine of mammals with distributions restricted to southern Nearctic and Neotropical regions. The known host range for aspidoderids includes xenarthrans (armadillos and anteaters), didelphiomorphs (opossums), hystricognath and sigmodontine rodents (Inglis, 1967), and a carnivore (Gomes and Pereira, 1970). The host spectrum has been established for several species of Aspidodera Railliet and Henry, 1912 (Santos et al., 1990). Two species in this family are notorious for their presence in several localities on the continent and for covering a wide host spectrum. These include Aspidodera raillieti Travassos, 1913 and Paraspidodera uncinata (Rudolphi, 1819). Both species appear to occur from Argentina to Mexico, with the former species reaching southern Illinois. Their ubiquitousness should expose them to almost any mammal in 
their range; however, they appear to infect a defined set of mammals. Three examples illustrate this point. First, in central Argentina, concurrent infections of any species of Paraspidodera, Aspidodera, and Nematomystes have not been reported in armadillos, didelphiomorph, and sigmodontine rodents (Navone, 1986, 1990; Navone and Suriano, 1992; Navone et al., 2009). Second, marsupials from French Guiana are infected exclusively by $A$. raillieti, not by $P$. uncinata, or any other species of Aspidodera (Byles, pers. comm.). Finally, A. raillieti commonly reaches $70 \%$ prevalence in marsupials (Gomes et al., 2003; Jiménez-Ruiz et al., 2011), yet it occurs in low prevalence and abundance in sympatric sigmodontine rodents, including $\mathrm{Nec}$ tomys squamipes (Pinto et al., 1982; Vicente et al., 1982; Gomes, 1984) and Euryoryzomys nitidus (unpubl. data). The presence of Proencaia heterospiculata Gomes and Pereira, 1970 in the margay, Leopardus weidii, has been considered as an accidental infection, on the basis of the presence of a sole individual in the large intestine of this carnivore (Jiménez-Ruiz et al., 2008).

On the basis of the evaluation of their morphological characters, it has been suggested that the ancestor of Aspidoderidae occurred in members of Dasypodidae (armadillos), and these subsequently switched in 3 separate events to hystricognath and geomyid rodents (cavy-like and pocket gophers, respectively) to myrmecophagans (anteaters), and finally to didelphids (opossums) and sigmodontine rodents (Jiménez-Ruiz et al., 2008).

To evaluate the evolutionary events that shaped the association among parasites and mammals, we attempted to reconstruct the ancestral distribution of the species involved in this putative switch. The emphasis was on those parasites known to occur in 4 groups of mammals, including didelphids, and sigmodontine, geomyid, and hystricognath rodents, as well as Nearctic species of Aspidoderidae.

\section{MATERIALS AND METHODS}

Several thousand mammals have been surveyed for parasites across the Neotropics since 1984 (Gardner and Hugot, 1995). The vast majority of individuals examined resulted from the inventory of the mammal diversity of Bolivia (Anderson, 1997), and includes a vast list of species from different orders. Some of the specimens infected with aspidoderid nematodes, as well as the localities where they were collected, are listed in Table I. For this study, the large intestine was opened, washed in water, and contents were examined with a dissecting microscope. Nematodes found were washed in water and immediately preserved in $95 \%$ ethanol or placed in cryotubes, frozen in liquid nitrogen, and stored at $-80 \mathrm{C}$. Both tail and anterior ends were cut and used to identify species and to serve as vouchers for deposit in museums. The rest of the body was used for extraction of DNA. Eleven species of Aspidoderidae were available for this study; at least 2 individuals of each species were analyzed, except for Aspidodera binansata Railliet and Henry, 1913, Lauroia bolivari JiménezRuiz and Gardner, 2003, and Nematomystes rodentiphilus Sutton, Chabaud and Durette-Desset, 1980.

An 800-bp fragment of the mitochondrial 16S rDNA (rrnL) and 900-bp fragment including internal transcriber spacers (ITS) 1 and 2 and 5.8 rDNA were amplified from whole-genome DNA extracted from individual male worms (QIAGEN DNeasy, Alameda, California). The rrnL fragment was amplified using primers $16 \mathrm{SCE}\left(5^{\prime}\right.$-ATTCTATCTCACAATGAATTAAAC-3') and C2F3 (5'-CGTCAATGTTCAGAAATTTGTGG-3') with cycling conditions of $94 \mathrm{C} / 4 \mathrm{~min}$; $(94 \mathrm{C} / 0: 30$ $\left.\min ; 48^{\circ} \mathrm{C} / 45 \mathrm{sec} ; 70 \mathrm{C} / 1 \mathrm{~min}\right) \times 35$; and $72 \mathrm{C} / 5 \mathrm{~min}$. The ITS fragment was amplified using primers NC2 (5'-TTAGTTTCTTTTCCTCCGCT-3') and NC5 (5'-GTAGGTGAACCTGCGGAAGGATCATT-3') (Gasser et al., 1993; Zhu et al., 1999) with cycling conditions of $90 \mathrm{C} / 135 \mathrm{sec}$; $(90 \mathrm{C} /$ $30 \mathrm{sec} ; 55 \mathrm{C} / 30 \mathrm{sec} ; 70 \mathrm{C} / 30 \mathrm{sec}) \times 35 ; 70 \mathrm{C} / 10 \mathrm{~min}$. Reactions were conducted in volumes of $25 \mu \mathrm{l}$ with $2.5 \mu \mathrm{l}$ of $10 \times$ buffer, $1.6 \mu \mathrm{l}$ of $50 \mathrm{mM}$ $\mathrm{MgCl}_{2}, 3.0 \mu \mathrm{l}$ of $\mathrm{dNTP}, 1$ unit of Taq polymerase, and $1.0 \mu \mathrm{l}$ of each primer at a concentration of $10 \mu \mathrm{M} / \mu \mathrm{l}$ and $100 \mathrm{ng}$ of DNA template, adjusting the volume with water.

Successfully amplified PCR products were purified using ExoSap-IT (GE Healthcare, Cleveland, Ohio) following manufacturer's recommendations. Purified products were processed with BigDye 3.2 (BigDye $^{\mathrm{TM}}$ Chemstry Perkin-Elmer Applied Biosystems) and direct sequenced in a Base Station 51 DNA Fragment Analyzer (MJ Research, Inc., Watertown, Massachusetts).

Resulting amplicons were aligned with Clustal W (http://www.genome. $\mathrm{jp} /$ tools/clustalw/), with gap opening penalty set at 40 , and gap extension penalty set at 10 . Sites of low probability were detected and removed using the algorithms implemented in the program GBlocks (http://molevol. cmima.csic.es/castresana/Gblocks_server.html), using default settings (Castresana, 2000). The cured alignments resulted in matrices of $665 \mathrm{bp}$ for $\operatorname{rrnL}$ and $595 \mathrm{bp}$ for ITS. The model of evolution GTR $+\mathrm{G}$ was selected for both matrices using Akaike information criterion as implemented in JModeltest (Posada, 2008).

Phylogenetic signal was analyzed using PAUP*, TreeFinder version November, 2008, and MrBayes 3.1.2 (Ronquist and Huelsenbeck, 2003; Swofford, 2003; Jobb et al., 2004), using parsimony and maximum likelihood as optimality criteria, and a Bayesian inference to estimate posterior probability of the nodes. In PAUP*, the phylogeny was reconstructed by means of a heuristic search with tree bisection reconnection branch swapping, 100 random additions of sequences, and 10 trees held at each replicate. One thousand bootstrap replicates were performed using a heuristic search in PAUP* and TreeFinder. MrBayes was set to run for 20 million generations with resampling every 1,000 iterations and a burn-in of $25 \%$ of the resulting trees. The remaining trees were used to reconstruct the consensus.

Cured matrices for $\operatorname{rrnL}$ and ITS were used to reconstruct the phylogeny of species for the 10 taxa included using the program BEAST* version 1.7 (Heled and Drummond, 2010). The species tree was reconstructed under a Yule model (Steel and McKenzie, 2001) with the following assumptions: constant population size; molecular clock with uniform rates across branches, and a general time reversible substitution model with gamma shape and 4 categories for both matrices.

Voucher specimens were deposited in the Harold W. Manter Laboratory of Parasitology of the University of Nebraska State Museum (Lincoln, Nebraska), resulting sequences were uploaded to Genbank ID JN852753-JN852778, JQ995297-JQ995322, and resulting trees were uploaded to TreeBase (http://purl.org/phylo/treebase/phylows/study/ TB2:S1 1985? x-access-code=44c612afe664950e8bb05cd469f4b8a5\&format $=\mathrm{html}$ and http://purl.org/phylo/treebase/phylows/study/TB2:S12695 ?x-access-code=a0d51406af8e3b4a5ff2c2143c7d1f5b\&format=html).

Historical associations among parasites and hosts were reconstructed by optimizing the mammals involved in the association in the phylogeny of Aspidoderidae. In this manner, every terminal in the phylogenetic tree was associated with a host taxon and used to reconstruct the ancestral host for the common ancestor of the parasites. Thirteen species of mammals belonging to 4 suprafamilial mammalian groups served as hosts for these parasites (Table I). Suprafamilial groups were selected to represent the association between species of nematodes and mammals. The purpose of this served 2 objectives, i.e., simplifying the reconstruction of ancestral states to reconstruct macroevolutionary events and avoiding sample bias toward a particular species in a given group. For example, we used the family name Dasypodidae to include Chaetophractus villosus, Dasypus novemcinctus, and Euphractus sexcinctus, common and abundant species of armadillos sampled for aspidoderid nematodes throughout their range (see Table I). We also used Hystricognathi, an infraorder of rodents with 10 families occurring in South America; from that total, 3 families include species infected by aspidoderids (Agoutidae, Caviidae, and Ctenomydae; Table I). These taxa were coded with a unique identifier: $0=$ Dasypodidae, $1=$ Hyscticognathi, $2=$ Geomyidae, $3=$ Sigmodontine, $4=$ Didelphidae, which include armadillos, cavy-like rodents, pocket gophers, Neotropical sigmodontines, and opossums, respectively (Table I). In this manner, the associations between parasites and hosts were treated as discrete characters to be optimized into the most parsimonious topologies of the parasite phylogeny reconstructed with both data sets. Reconstruction of associations was performed using parsimony and Bayesian inferences. Parsimony was used as optimality criteria as implemented in DIVA 1.1 (Ronquist, 1996). This method for reconstruction of ancestral states minimizes the number of extinctions and host-switching events to favor vicariant (cospeciation) events. The distribution of parasites in their hosts 


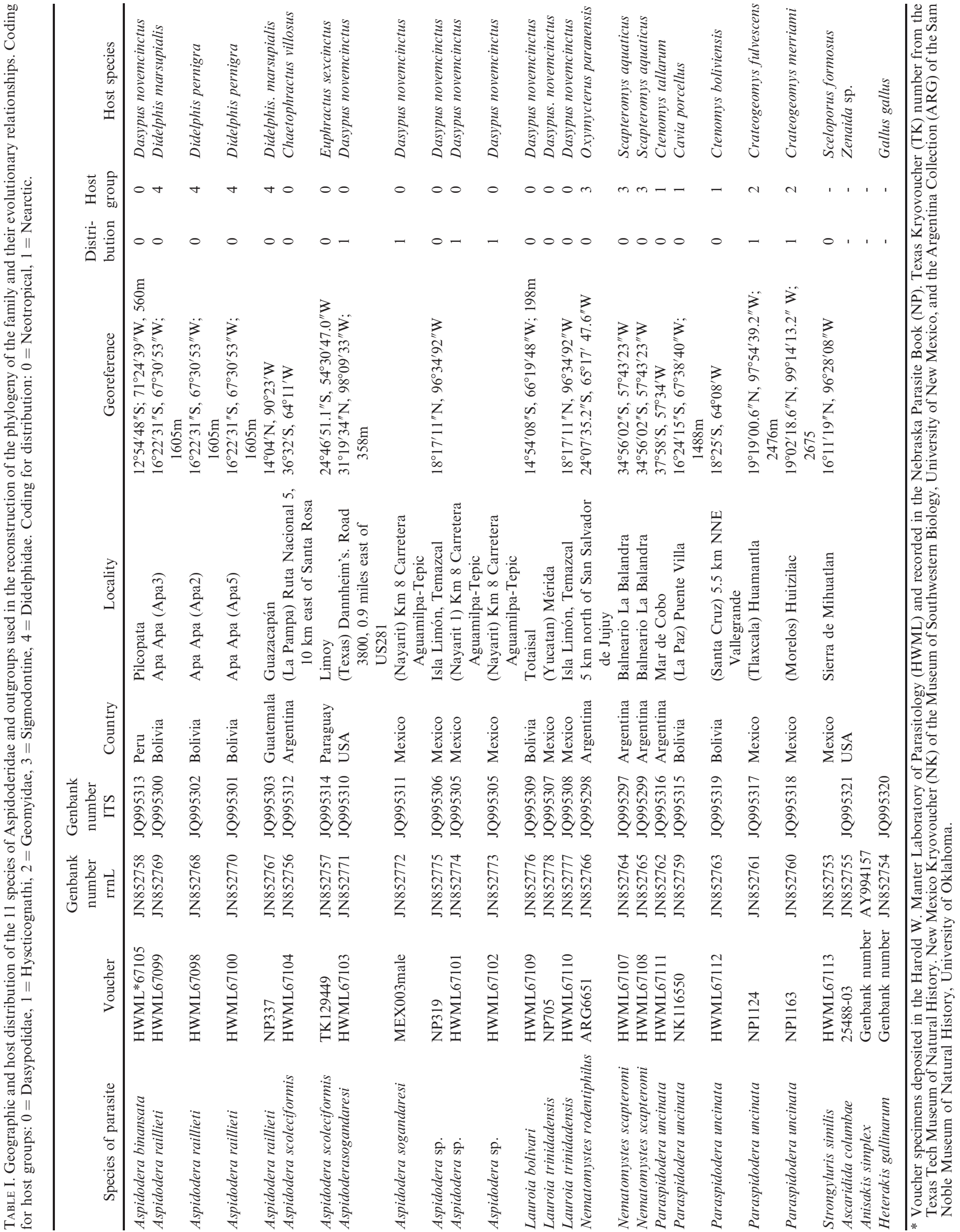



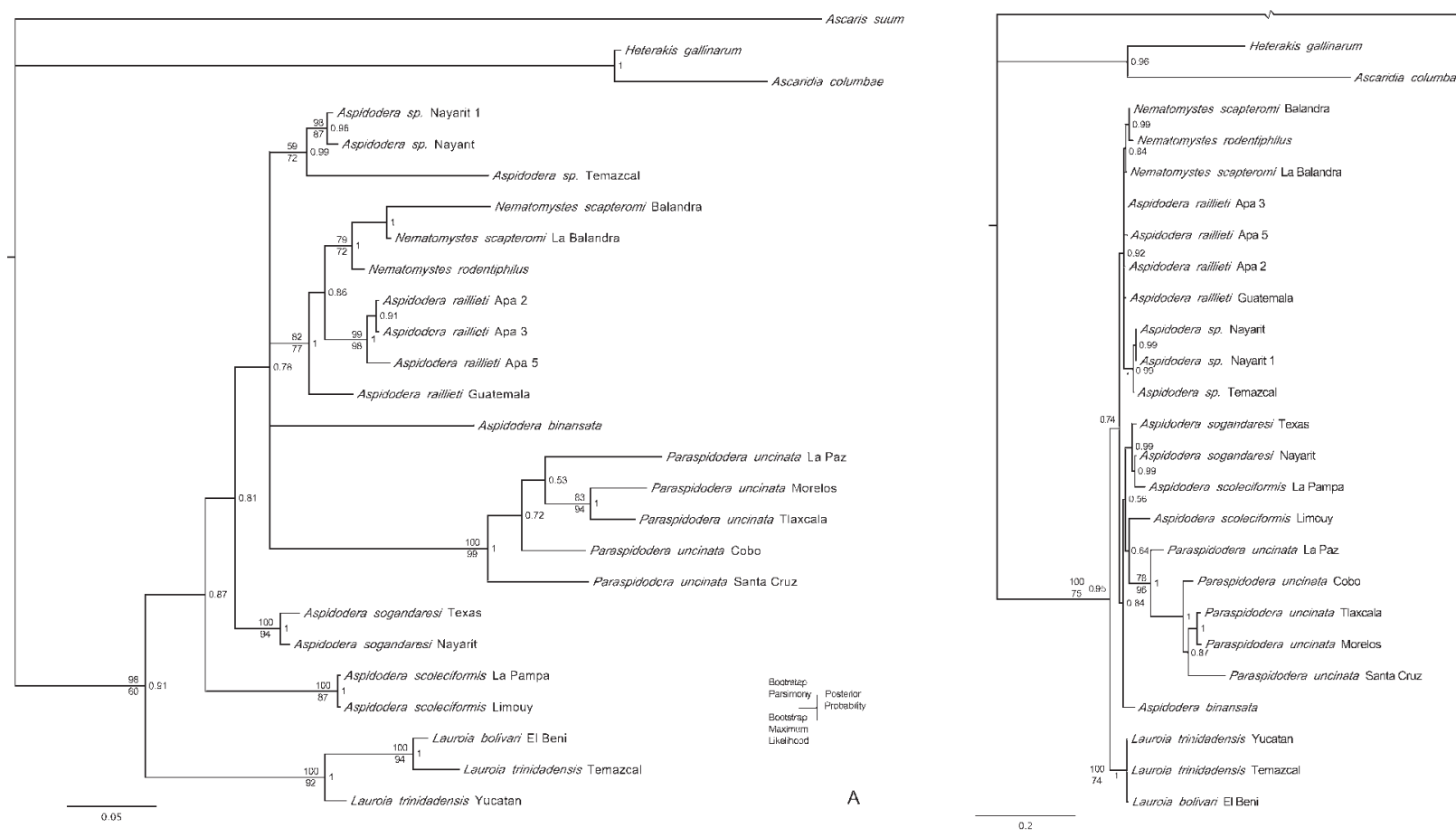

Ascoris sum

Figure 1. Bayesian inference of the relationships among aspidoderid nematodes. (A) Inference based on the mitochondrial ribosomal large subunit-rrnL. (B) Inference based on the internal transcriber spacers (ITS) 1 and 2 and 5.8 rDNA. Reconstructions based on 20 million generations. Posterior probabilities appear on the right and bootstrap values on the left; bootstrap values based on parsimony and maximum likelihood as optimality criteria appear on the upper and lower left, respectively. The symbol * in B indicates a bootstrap support of $100 \%$ for parsimony and $96 \%$ for maximum likelihood. All trees are available at Tree Base (http://purl.org/phylo/treebase/phylows/study/TB2:S12695? $\mathrm{x}$-access-code=a0d51406af8e3b4a5ff2c2143c7 dlf5b\&format $=\mathrm{html})$.

was converted to a binary matrix that was optimized into the phylogeny of Aspidoderidae.

A Bayesian reversible-jump Markov chain Monte Carlo simulation as implemented in BayesTraits 1.0 (Pagel et al., 2004) was used to reconstruct the ancestral hosts in all nodes of the parasite phylogeny. The algorithms implemented in BayesTraits derive the posterior probability and values of alternative traits at ancestral nodes of phylogenies. Traits showing the best fit to the node are selected as the optimal reconstructed character for that given node, making it possible to reconstruct evolutionary changes. The ancestral states of nodes in the phylogeny of Aspidoderidae were reconstructed for each of the 30,000 trees resulting from both chains of the Bayesian analyses. The distribution of the parasites in their hosts was scored as described above and treated as multistate characters. BayesMultistate allowed free host change among the 5 mammal groups mapped into the nodes of the parasite phylogeny. For the reconstruction of ancestral hosts, hyperprior exponential was seeded between 0 and 30 and the rate deviation was set at 10 , which resulted in acceptance rates between 20 and $40 \%$. A total of 100 million iterations was performed for each analysis with the first 100,000 samples discarded as burn-in with sampling every 1,000th generation. Each analysis was performed 3 times and the average of the harmonic mean was used for comparison against the results from the other constraints. Differences $<2$ units suggest strong support for the reconstruction of 1 character state over the others at a given node (Pagel et al., 2004).

The continental distribution of the parasites and their possible dispersion in the Nearctic was tested by scoring each of the terminals in the phylogeny of the Aspidoderidae as either Neotropical (0) or Nearctic (1). For purposes of this investigation, the divide between the Neotropical and Nearctic boundary was set at the Mexican transvolcanic axis; the Neotropics included the Pacific Province southward and the Nearctic included the Mesoamerican mountainous zone and the Xerophile Mexican Province northward (Cabrera and Willink, 1973). The ancestral geographical distribution of the parasites was reconstructed using parsimony and Bayesian approaches as described above. In this case, the 2 alternate states of character were analyzed using a hyperprior approach with an exponential prior seeded between 0 and 30 and setting the rate deviation to 90, which resulted in acceptance rates that oscillated between 20 and $40 \%$. Multiple preliminary analyses were performed to estimate the value of rate deviation that would produce acceptance levels within this range.

\section{RESULTS}

\section{Phylogeny}

A phylogenetic tree for Aspidoderidae using mitochondrial marker rrnL is presented on Figure 1A. This tree is the consensus resulting from the Bayesian inference and it includes the support for internal branches as calculated with each of the 3 algorithms. From the $665 \mathrm{bp}$ included, 259 are parsimony informative. The analysis of the rrnL using parsimony results in 3 equally parsimonious trees, which vary in the reciprocal relationships among species of Aspidodera. The topology resulting from Bayesian inference, parsimony, and maximum likelihood is concordant in that Aspidoderidae is a monophyletic group nested within the Heterakoidea and its support is higher than $90 \%$ using Bayesian inference and parsimony as optimality criteria, but $60 \%$ using maximum likelihood. In addition, the relationships among species of Aspidodera relative to Nematomystes appear unresolved, yet support for the monophyly of species of Lauroia Proença, 1938 and Paraspidodera Travassos, 1914, as well as for Aspidodera scoleciformis (Diesing, 1851) Railliet and Henry, 1912 and A. sogandaresi Jiménez-Ruiz, Gardner and Varela-Stokes, 2003, is higher than $90 \%$.

The phylogenetic tree resulting from the analysis of the ITS data set is shown in Figure 1B. This tree shows the topology 


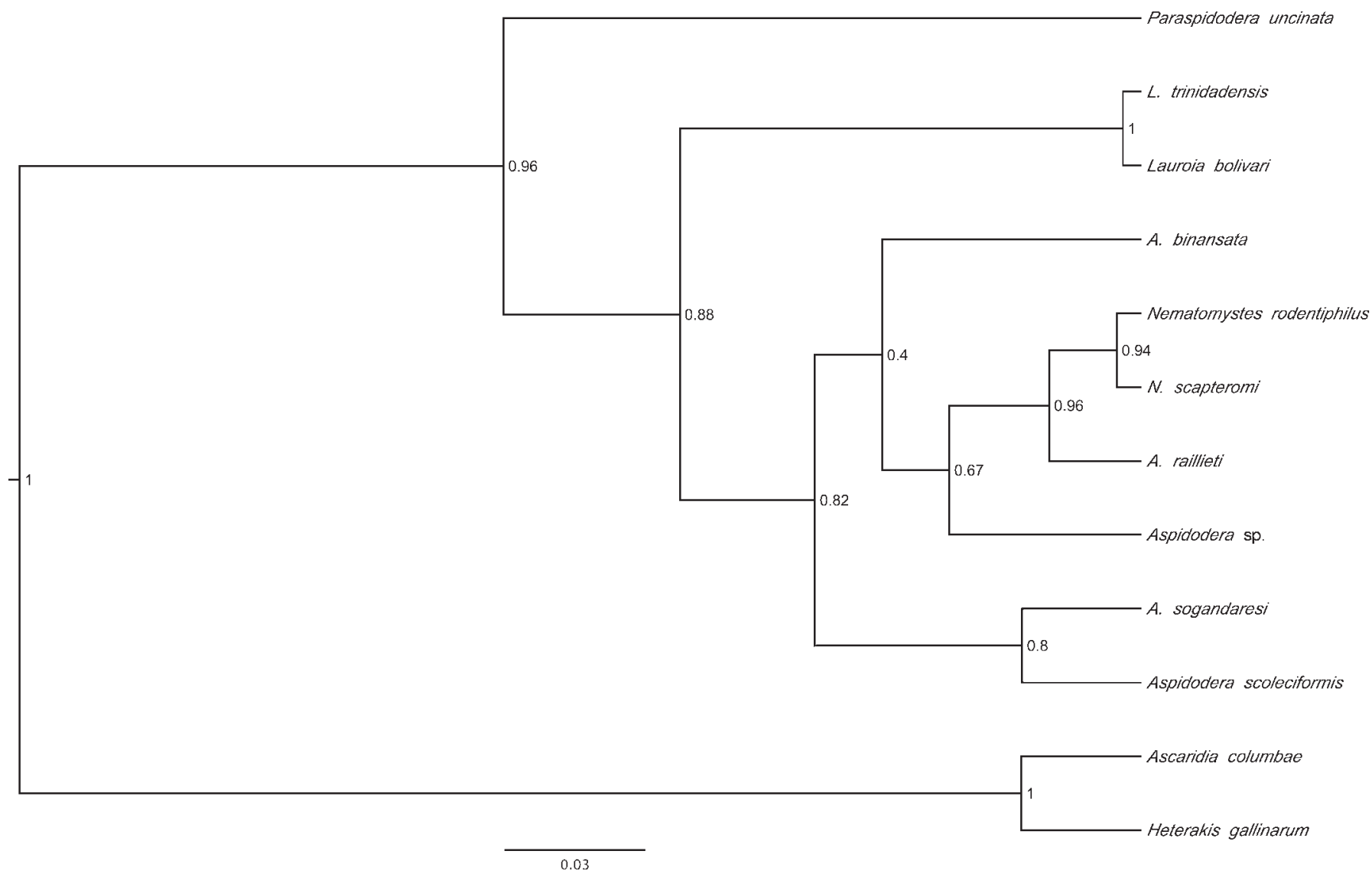

FIGURE 2. Phylogeny for 10 species of Aspidoderidae on the basis of the analysis of the mitochondrial ribosomal large subunit — rrnL — and internal transcriber spacers (ITS) 1 and 2 and 5.8 rDNA.

reconstructed by means of Bayesian inference and includes the support for the branches estimated by parsimony and maximum likelihood. The family is recovered as monophyletic irrespective of the optimality criteria used for the reconstruction. However, support is $75 \%$ when maximum likelihood was used as optimality criterion. From the 595 bp included, 224 are parsimony informative. The analysis based on parsimony results in 8 equally parsimonious trees, all of which show $A$. raillieti forming a polytomy with $N$. rodentiphilus. Deep nodes of the phylogeny, as well as those including $A$. raillieti, remain unresolved. All topologies show 3 groupings including species of Lauroia and Paraspidodera uncinata, as well as Aspidodera sp.

The species tree is presented in Figure 2. It shows a monophyletic family with support of 0.96 and 3 main clades, 1 including $P$. uncinata, which appears as the sister group for the rest of the species in the family. The other 2 clades show a support of 0.88 and contain both species of Lauroia with a support of 0.99 , and finally, the third clade has a support of 0.81 and it includes the 5 studied species of Aspidodera plus 2 of Nematomystes. In this latter clade, only the relationships between the 2 species of Nematomystes and A. raillieti show support greater than 0.95 (Fig. 2).

\section{Reconstruction of ancestral states: Continental distribution}

A total of 7 fully bifurcating trees was used in the reconstruction of ancestral states using parsimony as criteria.
Three resulted from the analyses of rrnL and 4 from ITS; 4 were eliminated from the latter because they were not bifurcated. These trees are available at http://purl.org/phylo/treebase/phylows/ study/TB2:S12695?x-access-code=a0d51406af8e3b4a5ff2c2143c7d $1 \mathrm{f} 5 \mathrm{~b} \&$ format $=\mathrm{html}$. The solution for the area reconstruction on the basis of these parsimonious trees suggest a Neotropical common ancestor for Aspidoderidae and 4 dispersion events in the Neartcic. Results using Bayesian inference do not show any significant difference in the reconstruction of the common ancestor of Aspidoderidae as either Neotropical or Nearctic. However, dispersion into the Nearctic is significant in 3 clades, including $P$. uncinata in Tlaxcala and Morelos (Mexico), Aspidodera sp. in Oaxaca and Nayarit (Mexico), and $A$. sogandaresi in Nayarit (Mexico) and Texas, which are supported by Bayes factor values of $1.38,1.25$, and 4.48 , respectively. The same clades had a support of 2.65, 2.68, and 2.17 using ITS topologies (Table II). Optimization of character states on 3 fully resolved species trees reveals the same 3 dispersals described above, yet it is ambiguous on the reconstruction of the ancestral origin for the family.

\section{Reconstruction of ancestral states: Associations with hosts}

The solution for the reconstruction of the association among aspidoderid nematodes and their hosts suggests 4 events of host switching (Fig. 3). First, a sigmodontine rodent is reconstructed as the host for the common ancestor of both species of 
TABLE II. Bayes factors for the reconstruction of the ancestral host at nodes of the phylogeny of Aspidoderidae. Historical associations between parasites and hosts were treated as discrete characters and reconstructed using a Bayesian reversible-jump Markov chain Monte Carlo simulation as implemented in BayesTraits (version 1.0). Reconstruction was made on trees resulting from the Bayesian inference of the posterior probabilities for the data sets rrnL and ITS, each consisting of 30,000 trees. Values in bold show the lowest average harmonic mean that permits the reconstruction of the ancestral host (columns) in selected nodes (rows).

\begin{tabular}{|c|c|c|c|c|c|c|c|c|c|c|}
\hline Node name & \multicolumn{2}{|c|}{ Dasypodidae } & \multicolumn{2}{|c|}{ Hystricognathi } & \multicolumn{2}{|c|}{ Geomyidae } & \multicolumn{2}{|c|}{ Sigmodontinae } & \multicolumn{2}{|c|}{ Didelphidae } \\
\hline Family & $-21.32 /$ & -21.68 & $-24.18 /$ & -24.65 & $-24.37 /$ & -25.11 & $-24.56 /$ & -24.27 & $-24.22 /$ & -23.094 \\
\hline Lauroia & $-20.91 /$ & -21.15 & $-27.71 /$ & -29.95 & $-27.89 /$ & $-30.03 /$ & $-27.62 /$ & -30.07 & $-27.45 /$ & -29.15 \\
\hline Paraspidodera uncinata & -25.23 & -23.1 & $-21.25 /$ & -22.48 & $-23.26 /$ & -23.58 & \multicolumn{2}{|c|}{-} & \multicolumn{2}{|c|}{-} \\
\hline P. uncinata South America & \multicolumn{2}{|c|}{-} & $-21.372 /$ & -21.69 & $-23.28 /$ & -23.63 & \multicolumn{2}{|c|}{-} & \multicolumn{2}{|c|}{-} \\
\hline P. uncinata Mexico & \multicolumn{2}{|l|}{ - } & $-23.66 /$ & -25.04 & $-21.05 /$ & -21.28 & \multicolumn{2}{|c|}{-} & \multicolumn{2}{|c|}{ - } \\
\hline
\end{tabular}

Nematomystes. Second, a didelphiomorph is reconstructed as the host for the common ancestor of $A$. raillieti and the 2 species of Nematomystes. Third, a hystricognath rodent is reconstructed as the host for the ancestor of P. uncinata occurring in Argentina and Bolivia. Finally, a geomyid rodent is reconstructed as the common ancestor for $P$. uncinata occurring in Mexico. The common ancestor of $P$. uncinata is ambiguously reconstructed as hystricognath or geomyid. Similarly, the common ancestor for

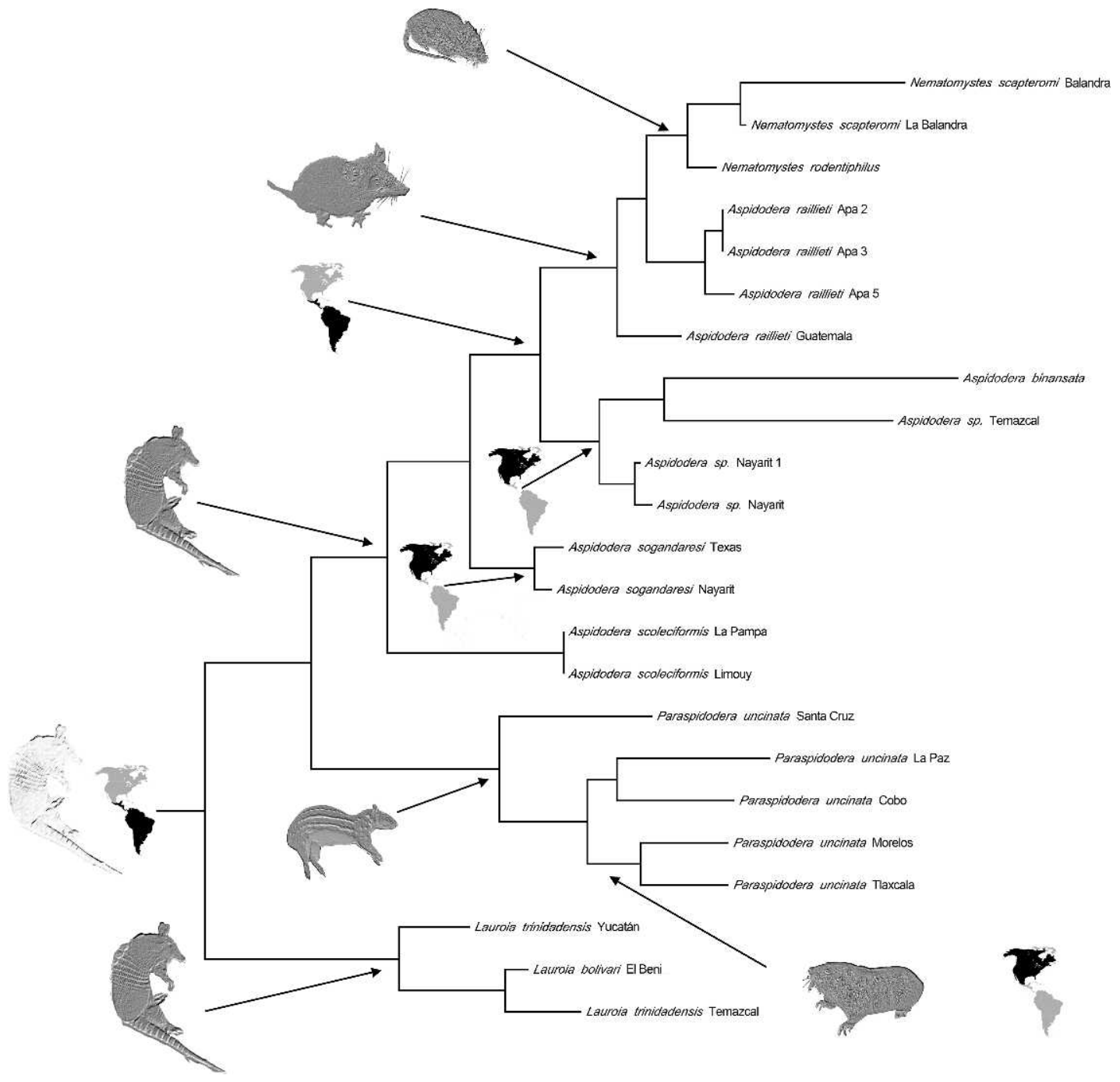

FIGURE 3. Reconstruction of evolutionary events in the diversification of Aspidoderidae. Four events of host switching localized in 2 clades are identified. Three dispersion events into the Nearctic are also illustrated. 
TABLE III. Bayes factors for the reconstruction of the ancestral area at nodes of the phylogeny of Aspidoderidae. Historical associations between parasites and hosts were treated as discrete characters and reconstructed using a Bayesian reversible-jump Markov chain Monte Carlo simulation as implemented in BayesTraits (version 1.0). Reconstruction was made on trees resulting from the Bayesian inference of the posterior probabilities for the data sets rrnL and ITS, each consisting of 30,000 trees. Values in bold show the lowest average harmonic mean that permits the reconstruction of the ancestral area (columns) for selected nodes (rows).

\begin{tabular}{|c|c|c|c|c|}
\hline \multirow[b]{2}{*}{ Node name } & \multicolumn{2}{|c|}{ Neotropical } & \multicolumn{2}{|c|}{ Nearctic } \\
\hline & $\operatorname{rrnL}$ & ITS & $\operatorname{rrnL}$ & ITS \\
\hline Family & $-12.37 /$ & -13.18 & $-12.31 /$ & -14.01 \\
\hline Aspidodera sp. & $-12.96 /$ & -13.03 & $-11.79 /$ & -15.72 \\
\hline Aspidodera sogandaresi & $-16.47 /$ & -14.9 & $-11.85 /$ & -12.96 \\
\hline Paraspidodera uncinata & $-12.04 /$ & -12.05 & $-12.15 /$ & -12.05 \\
\hline P. uncinata Mexico & $-13.81 /$ & -15.79 & $-11.84 /$ & -13.24 \\
\hline P. uncinata South America & $-12.1 /$ & -12.09 & $-12.14 /$ & -13.98 \\
\hline
\end{tabular}

Aspidoderidae is ambiguously reconstructed as a dasypodid or dasypodid/hystricognath/geomyid. The optimization of the host used on the phylogeny of the family using ITS resulted in the reconstruction of a dasypodid as the host for the ancestor of Aspidoderidae.

The reconstruction of ancestral states on the basis of Bayes factors is summarized in Table III. These results reveal lower harmonic means for Dasypodidae as the ancestral host at the 4 main nodes, including the common ancestor of the family and at least 3 deep clades (Fig. 3; Table III). Bayes factor values reveal lower harmonic means for didelphid marsupials as the ancestral host for A. raillieti and species of Nematomystes (Table III). A sigmodontine rodent is reconstructed as the ancestor for the 3 specimens in Nematomystes $(3.7 ; 2.92)$. The internal node supporting individuals of $P$. uncinata collected in both continents show similar values for Bayes factors for geomyid (2.85) and hystricognath rodents (3.16) relative to dasypodids. The independent analysis of each clade results in lower harmonic means for a hystricognath as the ancestral host for $P$. uncinata collected in South America, and for a geomyid as the ancestor for the parasites collected in Mexico. The reconstruction of ancestral distributions on 3 fully resolved species trees reveals 2 hostswitching events in the clade including Nematomystes and $A$. raillieti and in the basal splitting between $P$. uncinata and the rest of the species.

\section{DISCUSSION}

\section{Phylogenetic signal}

Both data partitions reveal that species traditionally included in Aspidodera are paraphyletic relative to species of Nematomystes and P. uncinata. Aspidodera does not appear to be monophyletic in that nominal species are included in 2 different clades with moderate support. The type species of the genus, A. scoleciformis, appears to be the sister group for $P$. uncinata, and the grouping of A. raillieti, $N$. rodentiphilus, and $N$. scapteromi shows a very high support. The rest of the species analyzed including Aspidodera sp. $A$. binansata and $A$. sogandaresi are part of independent clades with low support. The relationship among these species challenges the traditional division into subfamilies and highlights the unreliability of the anostomosing cordons in the definition of Aspidodera. This is apparent by the relative placement of Lauroia as the sister group for the rest of the species in the family and the grouping of $A$. scoleciformis and $P$. uncinata as sister groups. The synapomorphies that define the new groupings as well as the names proposed for each clade will be proposed elsewhere. It should be noted that several species endemic to Brazil, including A. ansirupta Proença, 1937, A. lacombae Vicente, 1964, Aspidodera subulata (Molin, 1860), A. vazi Proença, 1937, L. travassosi Proença, 1938, and Proencaia heterospiculata Gomes and Pereira 1970, were not available for this analysis. The inclusion of these missing species should help resolve the internal branches, improving the resolution of the relationships among members of Aspidodera.

Inclusion of additional specimens is also necessary for species already sampled, since it may provide evidence on their genetic variability. For example, $A$. binansata is represented by a single specimen collected in Bolivia, yet the species has a wide distribution and shows a relatively long branch. The problem is evident in the parsimony-based analyses, in which the species is included with specimens of an unnamed species of Aspidodera present in Mexico (Fig. 2).

The topology of the species tree is different from the rrnL and ITS trees in the placement of $P$. uncinata as the basal species for the family, yet it reveals Aspidodera as paraphyletic and it is congruent in the strong support for the sister group relationship among $A$. raillieti and both species of Nematomystes. In addition, it shows that the 2 species in Aspidodera present in Mexico and the United States are not reciprocal sister groups. In Figure 1A, A. sogandaresi appears as the sister group for A. scoleciformis, whereas the unnamed species of Aspidodera is part of a clade with low support grouping $A$. binansata, A. raillieti, and the 2 species of Nematomystes. Since specimens labeled as $P$. uncinata in Mexico appear to form a tight monophyletic group, it would be convenient treating these as a separate species in the reconstruction of the species tree. Additional samples throughout the continent are necessary to estimate any grouping formed by $P$. uncinata in South America.

\section{Reconstruction of ancestral states: Continental distribution}

The distribution of individual parasites was coded as either Neotropical or Nearctic depending on their collecting sites (Table I). For data sets rrnL and ITS, the parsimony-based analysis unequivocally reconstructs a Neotropical origin for the common ancestor of Aspidoderidae and reveals 3 dispersal events into the Nearctic. The only exception is the clade formed for $A$. sogandaresi, on the basis of optimization on the ITS topology since the reconstruction of its ancestral state is ambiguous. Perhaps because of the conflicting resolution at basal branches of the trees, values of Bayes factors are not conclusive for the reconstruction of the ancestor of the family as either Neotropical or Nearctic. This was also the case for most of the internal nodes; only 3 of the 11 nodes analyzed showed a perceptible difference in Bayes factor values (Pagel et al., 2004). This difference was strongly positive for the clade including $A$. sogandaresi. In the other 2 cases, the Bayes factor values were lower than 2, and could be interpreted as a moderate support for a Nearctic affinity of individuals of Aspidodera sp. and P. uncinata occurring in Mexico (Table II). This pattern suggests that 3 independent 
lineages dispersed into the Nearctic. In the case of $P$. uncinata, this dispersion would have been associated to hystricognath rodents moving northward (Simpson, 1980). The other 2 events involve Aspidodera sp. and A. sogandaresi, strict parasites of 9banded armadillos. These 2 species belong to different clades in the phylogeny (Figs. 1-3). This relationship suggests that at least 2 parasite lineages of Aspidodera entered the Nearctic independently, and it is consistent with empirical evidence showing the presence of 2 lineages of 9-banded armadillos that dispersed though Mexico (Arteaga et al., 2012). The origin and affinities of these 2 species of Aspidodera cannot be established with certainty because of the low support and credibility of the internal branches supporting Aspidodera sp.

\section{Reconstruction of ancestral states: Associations with hosts}

The reconstruction of Dasypodidae as the ancestor of the family appears strongly supported by Bayes factors (Table III). This suggests that the lineage that originated aspidoderid nematodes and the early diversification may have been associated with an ancestor of dasypodids (armadillos). Although this observation is congruent with the sequence of origin and diversification for Dasypodidae, dated $40 \pm 9$ mya (Delsuc et al., 2004), and hystricognaths in the new World, dated $33.8 \pm 1.8$ mya (Opazo, 2005), the reconstruction of the ancestor should be treated as ambiguous as indicated by all parsimony-based analyses. In addition, Dasypodidae is ambiguously reconstructed as the synapomorphic host for Aspidoderidae, as well as for each of the 3 main clades recovered in the phylogeny (Fig. 3).

Relative to the records that we presented herein, most of the specimens assigned to Aspidodera collected from dasypodids were recovered from 9-banded armadillos. Dasypus novemcinctus is the most common species in the family as well as the one showing the widest geographical distribution. The scale of our sampling prevents us from understanding the distribution of the parasites across the different species of dasypodids, especially in those localities where several species occur in sympatry. On the basis of this, it is yet unclear the degree of specificity of several species in Aspidodera toward the 21 recognized species in Dasypodidae (Gardner, 2007). There is no data set that allows a direct comparison of the distribution of these parasites in any of the species of armadillos occurring in sympatry.

In the phylogeny of the family, 2 of the internal nodes show an optimal reconstruction for ancestors other than dasypodids. This signifies that the 4 events of host switching are localized in 2 clades of the phylogeny of Aspidoderidae (Fig. 3). This suggests that, in Aspidoderidae, host switching is likely to occur in members of the same clade and perhaps there is an inherited ability that allow these parasites to do so. The features or ability that would allow these parasites to undergo host switching are presently unknown. Yet, it must be correlated with their ability to survive on the resources available in a wide host spectrum.

The first of these clades groups specimens of $P$. uncinata and the second includes $A$. raillieti and the 2 known species of Nematomystes. The hosts used by $A$. raillieti comprise didelphids (opossums) and sigmodontine rodents (water rats, long-nosed rats, among others), whereas $N$. rodentiphilus and $N$. scapteromi have been recorded only in sigmodontine rodents (Sutton et al., 1980; Gomes, 1984; Santos et al., 1990; Jiménez-Ruiz and Gardner, 2003; Chagas-Moutinho et al., 2007; Navone et al.,
2009). The ancestor for species of Nematomystes is reconstructed as a sigmodontine rodent, whereas the ancestor for $A$. raillieti + Nematomystes is reconstructed as a didelphid marsupial. This suggests a double event of host switching, first from dasypodids to didelphids, and then from didelphids to sigmodontine rodents. These events would coincide with the patterns of diversification of marsupials in South America (Voss and Jansa, 2009) and the invasion and subsequent patterns of diversification of sigmodontine rodents in South America (D'Elía, 2003; Steppan et al., 2004). The study of the timing and evolution of lineages of parasites is necessary to test this correlation. Aspidodera raillieti has been recorded in Illinois and other localities in the United States, always associated with didelphids (Chandler, 1932; Cordell, 1974). The species has also been recorded in sigmodontine rodents in South America (Pinto et al., 1982; Gomes, 1984). Since it appears that convergence in diet, life styles, and physiology play an important role in the distribution of the parasite in different mammals, one could be expected to find this parasite in insectivorous rodents endemic to North America, including grasshopper mice of the genus Onychomys.

The reconstruction of the ancestral host for the clade $A$. scoleciformis $+P$. uncinata suggests an event of host switching from dasypodids to either geomyid or hystricognath rodents. Both hystricognath and geomyid rodents show similar Bayes factor values, although these are slightly better for hystricognaths (Table III). Analyses of the 2 branches of this clade allow an unequivocal reconstruction of geomyids as the host for the ancestor of $P$. uncinata in Mexico. In the other branch, hysticognath rodents are reconstructed as a synapomorphy for $P$. uncinata collected in South America (Fig. 3). Hystricognaths and geomyids have quite distinct evolutionary histories and geographic origins (Spradling et al., 2004; Opazo, 2005; Poux et al., 2006). The dispersal of hystricognaths northward would have resulted in a host-switching event toward geomyids. Some species of geomyid and hystricognath rodents are sympatric across Central America (Hall, 2001). We attempted to collect aspidoderid nematodes in localities where both hystricognaths and geomyids are known to occur in sympatry, with no success.

In addition to physical proximity there are other traits that mammals involved in this host-parasite association have in common. For instance, geomyids (pocket gophers) and ctenomyds (tuco-tucos) display convergence in fossorial life styles and herbivorous diets, yet these contrast with the herbivorous diets of Guinea pigs and other hystricognaths known to be infected with $P$. uncinata. The rest of the mammals show variations of semifossorial habits, and insectivorous or omnivorous diets (armadillos and opossums). However, representatives of the groups sampled are known to display low metabolic rates, some as the result of their insectivorous diet (McNab, 2000), fossorial and semifossorial habits, and uptake of large amounts of dirt (McNab, 1984). The identification of the resource that species of Aspidoderidae depend on in these mammals, as well as the role, if any, of physiology in this association remain to be discovered.

Our results suggest that 4 events of host switching in Aspidoderidae allowed their establishment in didelphid marsupials, and sigmodontine, hystricognath, and geomyid rodents (Fig. 3). The compatibility of $P$. uncinata with both hystricognath and geomyid rodents, as well as the compatibility of $A$. raillieti with marsupials and sigmodontine rodents, suggests the capability of these parasites to infect mammals with similar characteristics. It 
also appears that the northward dispersion of 9-banded armadillos (Taulman and Robbins, 1996) carried 2 lineages of parasites with them, perhaps independently. The geographical expansion of hystricognaths and geomyids may have exposed geomyids to the parasites of hystricognaths and facilitated a switch and dissemination of this parasite through the southern edge of the Nearctic (Fig. 3). The analyses of protein-coding genes would allow the timing of the events of parasite diversification.

\section{ACKNOWLEDGMENTS}

We thank Laura A. Campbell for reading an earlier draft of this manuscript. Both work in the field and writing of this paper were supported by NSF grants BSR-8612329, BSR-9024816, DEB-9496263, DEB-9631295, DBI-0097019 to S.L.G. and the Hagan fund, the University of Nebraska State Museum and Faculty Seed Grants of the SIU College of Sciences to F.A.J. Virginia León-Règagnon, Sergio Guillén, Ana Malizia, Gerardo Pérez-Ponce de León, and Franklin Sogandares-Bernal provided specimens to complete our study.

\section{LITERATURE CITED}

Agosta, S. J., N. JAnZ, And D. R. Brooks. 2010. How specialists can be generalists: Resolving the "parasite paradox" and implications for emerging infectious disease. Zoologia 27: 151-162.

Anderson, S. 1997. Mammals of Bolivia, taxonomy and distribution. Bulletin of the American Museum of Natural History 231: 1-652.

Arteaga, M. C., D. Piñero, L. A. Eguiarte, J. Gasca, and R. A. Medellín. 2012. Genetic structure and diversity of the nine-banded armadillo in Mexico. Journal of Mammalogy 93: 547-559.

BRooks, D. R. 1985. Historical ecology: A new approach to studying the evolution of ecological associations. Annals of the Missouri Botanical Garden 72: 660-680.

Bueter, C., J. Weckstein, K. P. Johnson, J. M. Bates, and C. E. Gordon. 2009. Comparative phylogenetic histories of two louse genera found on Catharus thrushes and other birds. Journal of Parasitology 95: 295-307.

Cabrera, A. L., And A. Willink. 1973. Biogeografía de América Latina. Programa Regional de Desarrollo Científico y Tecnológico, Washington, D.C., $120 \mathrm{p}$.

Castresana, J. 2000. Selection of conserved blocks from multiple alignments for their use in phylogenetic analysis. Molecular Biology and Evolution 17: 540-552.

Chagas-Moutinho, V. A., A. Oliveira-Menezes, M. Q. Cárdenas, and R. M. LANFredi. 2007. Further description of Aspidodera raillieti (Nematoda: Aspidoderidae) from Didelphis marsupialis (Mammalia: Didelphidae) by light and scanning electron microscopy. Parasitology Research 101: 1331-1336.

Chander, A. C. 1932. Notes on the helminth parasites of the opossum (Didelphis virginiana) in southeast Texas, with descriptions of four new species. Proceedings of the United States National Museum 81: $1-15$.

Charleston, M. A. 1998. Jungles: A new solution to the host/parasite phylogeny reconciliation problem. Mathematical Biosciences 149: 191-223.

Choudhury, A., And T. A. Dick. 2001. Sturgeons (Chondrostei: Acipenseridae) and their metazoan parasites: Patterns and processes in historical biogeography. Journal of Biogeography 28: 1411-1439.

Combes, C. 1991. Evolution of parasite life cycles. In Parasite-host associations. Coexistence or conflict?, C. A. Toft, A. Aeschlimann, and L. Bolis (eds.). Oxford University Press, Oxford, U.K, p. 62-82.

Cordell, R. L. 1974. Helminth parasites of the Virginia opossum, Didelphis marsupialis virginiana, in Southern Illinois. M.S. Thesis. Southern Illinois University at Carbondale, Carbondale, Illinois, 55 p.

D’ElíA, G. 2003. Phylogenetics of Sigmodontine (Rodentia, Muroidea, Cricetidae), with special reference to the akodont group, and with additional comments on historical biogeography. Cladistics 19: 307323.

Delsuc, F., S. F. Vizcaíno, and E. J. P. Douzery. 2004. Influence of Tertiary paloenvironmental changes on the diversification of South
American mammals: A relaxed molecular clock study with xenarthrans. BioMed Central Evolutionary Biology 4: 11 .

Dunnum, J. L., and J. Salazar-Bravo. 2010. Molecular systematics, taxonomy and biogeography of the genus Cavia (Rodentia: Caviidae). Journal of Zoological Systematics and Evolutionary Research 48: $376-388$

Gardner, A. L. 2007. Mammals of South America. Chicago University Press, Chicago, Illinois, 669 p.

Gardner, S. L., AND J. P. Hugot. 1995. A new pinworm, Didelphoxyuris thylamisis n. gen., n. sp. (Nematoda: Oxyurida) from Thylamys elegans (Waterhouse, 1839) (Marsupialia: Didelphidae) in Bolivia. Research and Reviews in Parasitology 55: 139-147.

Gasser, R. B., N. B. Chilton, H. Hoste, and I. Beveridge. 1993. Rapid sequencing of rDNA from single worms and eggs of parasitic helminths. Nucleic Acids Research 21: 2525-2526.

Gomes, D. C. C. 1984. Helmintos parasitos de Nectomys squamipes (Brants) do Municipio de Sumidouro, RJ. Memorias do Instituto Oswaldo Cruz 79: 67-73.

, R. P. da Cruz, J. J. Vicente, and R. M. Pinto. 2003. Nematode parasites of marsupials and small rodents from the Brazilian Atlantic rain forest in the State of Rio de Janeiro, Brazil. Revista Brasileira de Biologia 20: 699-707.

, and R. C. S. Pereira. 1970. Sôbre um nôvo gênero da família "Lauroiinae" Skrjanin and Shikhobalova, 1951 (Nematoda, Subuluroidea). Atas da Sociedade Biologica do Rio de Janeiro 12: 35-37.

Hall, E. R. 2001. The mammals of North America, 2nd ed., Vol. 1 Blackburn Press, Caldwell, New Jersey, 181 p.

Heled, J., And A. J. Drummond. 2010. Bayesian inference of species trees from multilocus data. Molecular Biology and Evolution 27: 570-580.

Huelsenbeck, J. P., and B. Rannala. 1997. Phylogenetic methods come of age: Testing hypotheses in an evolutionary context. Science 276: $227-232$. analysis of cospeciation. Evolution 54: 352-364.

Huyse, T., and F. A. M. Volckaert. 2005. Comparing host and parasite phylogenies: Gyrodactylus flatworms jumping from goby to goby. Systematic Biology 54: 710-718.

IngLIS, W. G. 1967. The evolution, host relationships and classification of the nematode superfamily Heterakoidea. Bulletin of the British Museum (Natural History) 15: 3-28.

JANZEN, D. H. 1980. When is it coevolution? Evolution 34: 611-612.

JimÉnez-Ruiz, F. A., And S. L. Gardner. 2003. Aspidoderid nematodes from Bolivian armadillos, with the description of a new species of Lauroia (Heterakoidea: Aspidoderidae). Journal of Parasitology 89: 978-983.

, AND F. CATZEFLIS. 2011. Structure of parasite componen communities of didelphid marsupials: Insight from a comparative study. Journal of Parasitology 97: 779-787.

- , D. Noronha, and R. M. Pinto. 2008. The systematic position of Lauroiinae Skrjabin and Schikhobalova, 1951 (Nemata: Heterakoidea: Aspidoderidae), as revealed by the analysis of traits used in its diagnosis. Cladistics 24: 459-476.

Jobb, G., A. von Haeseler, and K. Strimmer. 2004. TREEFINDER: A powerful graphical analysis environment for molecular phylogenetics. BMC Evolutionary Biology 4: 18.

Kelly, D. W., R. A. Paterson, C. R. Townsend, R. Poulin, and D. M. TOMPKINS. 2009. Parasite spillback: A neglected concept in invasion ecology? Ecology 90: 2047-2056.

Kishino, H., AND M. Hasegawa. 1989. Evaluation of the maximum likelihood estimate of the evolutionary tree topologies from DNA sequence data, and the branching order of Hominoidea. Journal of Molecular Evolution 29: 170-179.

Light, J. E., AND M. D. Hafner. 2008. Codivergence in heteromyid rodents (Rodentia: Heteromyidae) and their sucking lice of the genus Fahrenholzia (Phthiraptera: Anoplura). Systematic Biology 57: 449465.

$\mathrm{MCN}_{\mathrm{AB}}$, B. 1984. Physiological convergence amongst ant-eating and termite-eating mammals. Journal of Zoology, London 203: 485-510 - 2000. Metabolic scaling - Energy constraints on carnivore diet. Nature 407: 584-584.

NAvone, G. T. 1986. Estudios parasitológicos en edentados argentinos. II Nematodes parásitos de armadillos: Aspidodera fasciata (Schneider, 1866); Aspidodera scoleciformis (Diesing, 1851) y Aspidodera vazi 
Proença, 1937. (Nematoda-Heterakoidea). Neotropica. La Plata 32: 71-79.

-1990. Estudio de la distribución, porcentaje y microecología de los parásitos de algunas especies de edentados argentinos. Studies on Neotropical Fauna and Environment 25: 199-210.

-, J. Notarnicola, S. Nava, M. R. Robles, C. Galliari, and M. LARESCHI. 2009. Arthropods and helminths assamblage in sigmodontine rodents from wetlands of the Rio de la Plata. Argentina Mastozoología Neotropical 16: 121-133.

—, AND D. M. SuRIANO. 1992. Species composition and seasonal dynamics of the helminth community parasitizing Didelphis albiventris (Marsupialia: Didelphidae) in savannas of central Argentina. Ecologia Austral 2: 95-1000.

Opazo, J. C. 2005. A molecular timescale for caviomorph rodents (Mammalia, Hystricognathi). Molecular Phylogenetics and Evolution 37: 932-937.

Pagel, M., A. Meade, and D. Barker. 2004. Bayesian estimation of ancestral character states on phylogenies. Systematic Biology 53: 673684.

Pinto, R. M., A. Kohn, B. M. M. Fernandes, and D. A. Mello. 1982. Nematodes of rodents in Brazil, with description of Aspidodera vicentei n.sp. Systematic Parasitology 4: 263-267.

Posada, D. 2008. jModelTest: Phylogenetic model averaging. Molecular Biology and Evolution 25: 1253-1256.

Poux, C., P. Chevret, D. Huchon, W. W. De Jong, and E. J. P. Douzery. 2006. Arrival and diversification of caviomorph rodents and platyrrhine primates in South America. Systematic Biology 55: 228 244.

Ronquist, F. 1996. DIVA. Computer program and manual available by anonymous FTP from Uppsala University (ftp.uu.se or ftp.systbot. uu.se), Uppsala, Sweden.

. 2001. TreeFitter. Uppsala University, Uppsala, Sweden.

2003. Parsimony analysis of coevolving associations. In Tangled trees: Phylogeny, cospeciation, and coevolution, R. D. M. Page (ed.). Chicago University Press, Chicago, Illinois, 22-64 p.

— and J. P. Huelsenbeck. 2003. MRBAYES 3: Bayesian phylogenetic inference under mixed models. Bioinformatics 19: 1571-1574.

Santos, C. P., H. Lent, and D. C. Gomes. 1990. The genus Aspidodera Railliet and Henry, 1912 (Nematoda: Heterakoidea): Revision, new synonyms and key for species. Revista Brasileira do Biologia 50: $1017-1031$.
Simpson, G. G. 1980. Splendid isolation. The curious history of South American mammals, 1st ed. Yale University Press, New Haven, Connecticut, $266 \mathrm{p}$.

Sмyth, J. D. 1962. Introduction to animal parasitology, 1st ed. The English University Press Ltd., London, U.K, 470 p.

Spradling, T. A., S. V. Brant, M. S. Hafner, and C. J. Dickerson. 2004 DNA data support a rapid radiation of pocket gopher genera (Rodentia: Geomyidae). Journal of Mammalian Evolution 11: 105125.

Steel, M., And A. McKenzie. 2001. Properties of phylogenetic trees generated by Yule-type speciation models. Mathematical Biosciences 170: $91-112$.

Steppan, S. J., R. M. Adkins, and J. Anderson. 2004. Phylogeny and divergence-date estimates of rapid radiations in muroid rodents based on multiple nuclear genes. Systematic Biology 53: 533-553.

Sutton, C. A., A. G. Chabaud, and M. C. Durette-Desset. 1980. Contribución al conocimiento de la fauna parasitológica argentina. VI. Sobre un nuevo Lauroiinae (Nematoda, Ascaridida). Bulletin Du Muséum National d'Histoire Naturelle. Section A: Zoologie: Biologie et Écologie Animales 2: 81-85.

Swofford, D. L. 2003. PAUP*. Phylogenetic analysis using parsimony (*and other methods). Sinauer Associates, Sunderland, Massachusetts.

Taulman, J. F., And L. W. Robbins. 1996. Recent range expansion and distributional limits of the nine-banded armadillo (Dasypus novemcinctus) in the United States. Journal of Biogeography 23: 635-648.

Vicente, J. J., D. C. C. Gomes, and N. A. D. Araujo. 1982. Alguns helmintos de marsupiais e roedores da Ilha Grande, Estado do Rio de Janeiro. Atas da Sociedade de Biologia do Rio de Janeiro 23: 3-4.

Voss, R. S., AND S. A. JANSA. 2009. Phylogenetic relationships and classification of didelphid marsupials, and extant radiation of New World metatherian mammals. Bulletin of the American Museum of Natural History 322: 1-177.

WeCKStein, J. D. 2004. Biogeography explains cophylogenetic patterns in chewing lice. Systematic Biology 53: 154-164.

Weksler, M. 2006. Phylogenetic relationships of oryzomine rodents (Muroidea: Sigmodontinae): Separate and combined analyses of morphological and molecular data. Bulletin of the American Museum of Natural History 296: 1-149.

Zhu, X. Q., N. B. Chilton, D. E. Jacobs, J. Boes, and R. B. Gasser. 1999. Characterisation of Ascaris from human and pig hosts by nuclear ribosomal DNA sequences. International Journal for Parasitology 29: $469-478$ 